\title{
Repeatability of agronomic traits in Panicum maximum (Jacq.) hybrids
}

\author{
T.G.S. Braz ${ }^{1}$, D.M. Fonseca ${ }^{2}$, L. Jank ${ }^{3}$, C.D. Cruz $^{4}$ and J.A. Martuscello ${ }^{5}$ \\ ${ }^{1}$ Departamento de Zootecnia, Universidade Federal dos Vales do Jequitinhonha e Mucuri, \\ Diamantina, MG, Brasil \\ ${ }^{2}$ Departamento de Zootecnia, Universidade Federal de Viçosa, Viçosa, MG, Brasil \\ ${ }^{3}$ Embrapa Beef Catle, Cytogenetics Laboratory, Campo Grande, MS, Brasil \\ ${ }^{4}$ Departamento de Biologia Geral, Universidade Federal de Viçosa, Viçosa, MG, Brasil \\ ${ }^{5}$ Departamento de Zootecnia, Universidade Federal de São João del-Rei, \\ São João del-Rei, MG, Brasil \\ Corresponding author: T.G.S. Braz \\ E-mail: thiago-braz@hotmail.com
}

Genet. Mol. Res. 14 (4): 19282-19294 (2015)

Received August 13, 2015

Accepted October 2, 2015

Published December 29, 2015

DOI http://dx.doi.org/10.4238/2015.December.29.38

ABSTRACT. When evaluating plants, in particular perennial species, it is common to obtain repeated measures of a given trait from the same individual to evaluate the traits' repeatability in successive harvests. The degree of correlation among these measures defines the coefficient of repeatability, which has been widely utilized in the study of forage traits of interest for breeding. The objective of the present study was to evaluate the repeatability of agronomic traits in Panicum maximum hybrids. Hybrids from three progenies totaling 320 hybrids were evaluated in an incompleteblock design, with consideration of production and morpho-agronomic traits. Of the production traits, total dry matter and leaf dry matter showed the highest repeatability and varied from 0.540 to 0.769 , whereas stem dry matter had lower coefficients (0.265-0.632). Among the morpho-agronomic traits, plant height and incidence of Bipolaris maydis had higher coefficients (0.118-0.460). The repeatability values of the agronomic traits were low-to- 
moderate, and six evaluations were sufficient to provide accuracy in the selection of hybrids regarding total dry matter, leaf dry matter, plant height, and incidence of $B$. maydis, whereas the other traits require more repeated measures to increase reliability in the prediction of their response.

Key words: Bipolaris maydis; Forage production; Genetic breeding; Leaf mass; Regrowth; Repeated measures.

\section{INTRODUCTION}

Over the last 40 years, the area of cultivated-pasture in Brazil has increased from 29.7 to 101.4 million hectares (SIDRA-IBGE, 2011). This increase is mainly due to agricultural advances and the substitution of native for exotic forages. However, large parts of these areas are planted with a few cultivars that undergo apomictic (clonal) reproduction, representing extensive clonal monocultures, which have little variability and are extremely vulnerable genetically (Valle et al., 2009).

Diversification achieved through the growth of better adapted and competitive forage plants is essential for mitigating problems associated with monoculture. In this sense, the Panicum maximum Jacq. species is an excellent option for use in the diversification and intensification of Brazilian pastures, since it is widely used among stock-growers and is considered to be one of the most productive and competitive species in the national livestock scenario (Jank et al., 2008). Genetic breeding of forage by the introduction of accessions has been practiced as the principal means of launching new cultivars (Jank et al., 2011). However, despite being simple and timely, this method provides finite gains, as it is based solely on the evaluation of the adaptive ability of accessions collected in nature. Breeding forage plants through genetic recombination is therefore the best option to generate new cultivars (Valle et al., 2009).

In the plant evaluation process - perennial plants especially - it is common to take repeated measures of a given trait in the same individual. This type of evaluation aims to infer a genotype's ability to repeat its performance over successive evaluations. The degree of correlation among repeated measures in the same individual in time or space statistically defines the coefficient of repeatability (Cruz et al., 2004).

In perennial plants propagated by apomixis, estimates of the repeatability coefficient indicate the level of influence that permanent effects have on the observed phenotypic variation, and allows the performance of individuals to be predicted (Falconer and Mackay, 1996; Di Renzo et al., 2000). In addition, repeatability expresses the maximum value that heritability in the broad sense can reach, as it expresses the proportion of phenotypic variance that is attributed to the genetic differences mistaken for permanent effects acting on a cultivar or on progeny. In this context, the repeatability coefficient approaches the heritability coefficient when the variance provided by the permanent effects of the environment is reduced. Thus, repeatability is an essential reference that can be used to guide genetic breeding studies (Shimoya et al., 2002; Cruz et al., 2004). Furthermore, according to Falconer and Mackay (1996), when a plant is measured multiple times, the average of these measures can be used to estimate the genotypic value of the trait in question. Thus, the objective of this study was to evaluate the repeatability of agronomic traits in $P$. maximum/ hybrids.

\section{MATERIAL AND METHODS}

The experiment was conducted at Embrapa Beef Cattle, located in the municipality of 
Campo Grande/MS, Brazil (20 $27^{\prime}$ latitude and $54^{\circ} 57^{\prime}$ longitude). According to the Köppen classification, the climate is a tropical rainy savannah type, Aw sub-type, characterized by irregular annual distribution of rain and by a well-defined dry period during the cold months and a rainy period during the summer. The mean maximum and minimum temperatures during the experimental period were $34.3^{\circ}$ and $14.1^{\circ} \mathrm{C}$, respectively; accumulated annual precipitation was $1416 \mathrm{~mm}$. Climatic data were collected at a meteorological station located approximately $500 \mathrm{~m}$ from the experimental area (Figure 1).

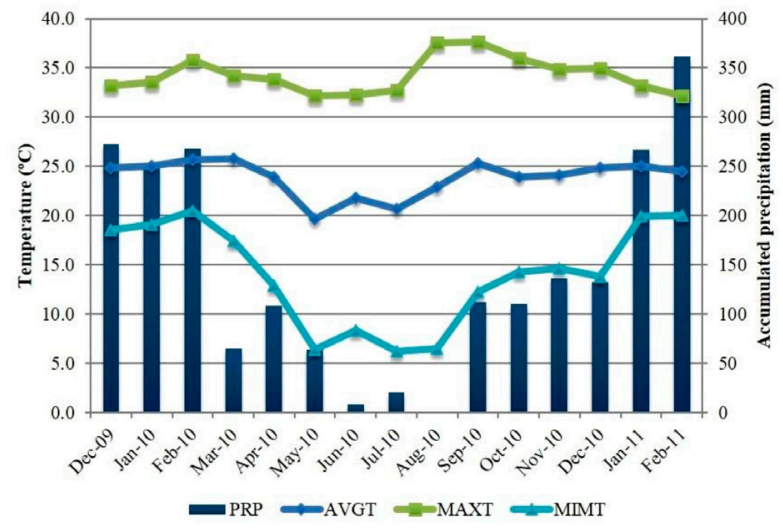

Source: Meteorological station at Embrapa Beef Cattle

Figure 1. Accumulated precipitation (PRP), and average (AVGT), maximum (MAXT), and minimum (MINT) temperatures recorded during the experimental period.

In the study, hybrid individuals from three progenies from full siblings of $P$. maximum were evaluated. These hybrids were obtained by crossings made between four potential parents: sexual mother plants S10 and S12, and apomictic cultivars Mombaça and Tanzania, which were pollen donors. Progeny 1 resulted from a cross between sexual plant S10 and Tanzania grass; progeny 2 resulted from a cross between the same sexual plant and Mombaça grass; and progeny 3 was the result of a cross between sexual parent S12 and Tanzania grass.

The seeds were obtained by polycross blocks in May and June 2007, when the mother polyploid plants were placed amidst the $25-\mathrm{m}^{2}$ plots established with the parents to increase pollen density and reduce selfing. The seeds were germinated in December 2007 and transplanted to plastic bags in a greenhouse in February 2008, where they remained until they showed sufficient growth to be transplanted to the field, which occurred in November 2008.

Chemical analysis of soil was performed with the $0-20 \mathrm{~cm}$ layer (Table 1). Based on the results, $120 \mathrm{~kg} / \mathrm{ha} \mathrm{P}_{2} \mathrm{O}_{5}$ was applied in the form of single superphosphate during plot establishment in the field. The experimental area was prepared by the conventional method, including plowing, application of limestone, and harrowing at the end of the rainy season before the seedlings were transplanted to the field. During the experimental period, plants were fertilized annually with 100 $\mathrm{kg} / \mathrm{ha} \mathrm{N}, 100 \mathrm{~kg} / \mathrm{ha} \mathrm{K}_{2} \mathrm{O}$, and $100 \mathrm{~kg} / \mathrm{ha} \mathrm{P}_{2} \mathrm{O}_{5}$. These fertilizer applications were performed once at the beginning of the rainy season.

After establishment, the final number of hybrids was 108 for progeny one, 167 hybrids for progeny two, and 45 hybrids for progeny three, totaling 320 hybrids, which were subsequently cloned and evaluated in a clonal test in an incomplete-block design with 320 treatments and two 
replicates. Blocks consisted of three linear plots with nine plants (tussocks), totaling 32 blocks. Each plot corresponded to one of the abovementioned progenies. Mombaça-grass plants were inserted in the borders. Plants within and between rows were spaced 1-m apart.

Table 1. Soil chemical characteristics of the $0-20 \mathrm{~cm}$ layer in the experimental area.

\begin{tabular}{lc}
\hline Component & Concentration \\
\hline $\mathrm{pH} \mathrm{H} \mathrm{H}_{2} \mathrm{O}$ & 5.10 \\
$\mathrm{P}\left(\mathrm{mg} / \mathrm{dm}^{3}\right)$ & 2.61 \\
$\mathrm{~K}\left(\mathrm{mg} / \mathrm{dm}^{3}\right)$ & 17.70 \\
$\mathrm{Ca}\left(\mathrm{cmol}_{\mathrm{c}} / \mathrm{dm}^{3}\right)$ & 6.56 \\
$\mathrm{Mg}\left(\mathrm{cmol}_{\mathrm{l}} / \mathrm{dm}^{3}\right)$ & 1.62 \\
$\mathrm{Al}\left(\mathrm{cmol}_{\mathrm{c}} / \mathrm{dm}^{3}\right)$ & 0.11 \\
$\mathrm{H}+\mathrm{Al}_{\mathrm{c}}\left(\mathrm{cm}^{3}\right)$ & 3.01 \\
Base saturation $(\%)$ & 57.17 \\
Aluminium saturation $(\%)$ & 2.70 \\
Organic matter (dag/kg) & 3.24 \\
\hline
\end{tabular}

The hybrids were managed by cuts made $25 \mathrm{~cm}$ above the soil, on 01/26/10, 03/08/10, 06/05/10, 10/05/10, 11/18/10, 12/29/10, and 02/03/11. The cut made on 06/05/2010 was not assessed because it occurred immediately after full flowering of the hybrids, which was also when seeds were collected for future studies. In each cut, the forage was harvested, weighed, and subsequently sampled. In sampling, the following morphological components were separated: leaf blades, stems + sheaths, and dead forage; these were later dried to determine the dry weight and their relative participation in the morphological composition of samples. The following agronomic traits were evaluated: total dry matter production (TDM, g/plant), leaf dry matter (LDM, g/plant), dry matter of stem + sheath (SDM, g/plant), and percentage of leaves $(\% \mathrm{~L})$. $\% \mathrm{~L}$ was estimated as the proportion of leaf blade dry matter and the sum of the dry matter of blades and stem + sheaths from the morphological separation, i.e., the ratio between the dry matter of blades and the green dry matter. Plant height (HGT, cm), regrowth (RGH), and incidence of the fungus Bipolaris maydis (IBM) were also evaluated. The height was measured on the day before the plants were cut, using a millimeter ruler.

Plant regrowth was evaluated 7 days after the cuts were made. This value integrates two other traits: density and speed. The regrowth density was evaluated by assigning scores of $1-5$, where 1 corresponded to regrowth of $0-20 \%$ of tillers, and 5 corresponded to regrowth of 80 $100 \%$ of tillers. The regrowth speed, however, was determined by assigning scores of -1 (slow), 0 (medium), and 1 (fast). The plant regrowth value was calculated by adding up these two variables, and varied from 0 to 6 . To evaluate IBM, a subjective evaluation was also employed, by assigning scores of $1-5$, where 1 corresponded to an incidence of $0-20 \%$, and 5 corresponded to an incidence of $80-100 \%$. This evaluation was also performed on the day before plant cutting. Traits were divided into production (TDM, LDM, and SDM) and morpho-agronomic (\%L, HGT, RGH, and IBM) traits to facilitate the discussion of results.

The repeatability coefficient estimate was obtained by using analysis of variance (ANOVA), principal component analysis based on the phenotypic variance-covariance matrix (PCCOV), principal components analysis based on the intraclass correlation matrix (PCCOR), and the structural analysis method based on the correlation matrix (STRU), as described by Cruz et al. (2004). To estimate the repeatability coefficient by ANOVA, a statistical model with two sources of variation was adopted:

$$
\boldsymbol{Y}_{\boldsymbol{i} \boldsymbol{j}}=\boldsymbol{\mu}+\boldsymbol{g}_{\boldsymbol{i}}+\boldsymbol{a}_{\boldsymbol{j}}+\boldsymbol{e}_{\boldsymbol{i} \boldsymbol{j}}
$$


where $\mu=$ overall mean; $g_{i}=$ effect of the $i$-th hybrid individual; $a_{j}=$ effect of environment at the $j$-th measurement; $e_{i j}=$ effect of the temporary environment associated with the $j$-th measurement in the it-h genotype. For this model, the repeatability coefficient was determined as:

$$
r=\frac{\operatorname{cov}\left(Y_{i j}, Y_{i j^{\prime}}\right)}{\sqrt{V\left(Y_{i j}, Y_{i j^{\prime}}\right)}}=\frac{\widehat{\sigma}_{g}^{2}}{\widehat{\sigma}^{2}+\widehat{\sigma}_{g}^{2}}
$$

where $\hat{\sigma}_{g}^{2}$ is the covariance among the measures repeated in each genotype, and $\hat{\sigma}^{2}$ is the residual variance. The coefficient of repeatability was estimated by the principal component analysis method, based on the phenotypic variance-covariance matrix and on the phenotypic correlation matrix. The correlation matrix method was proposed by Abeywardena (1972), and is based on obtaining the matrix of correlations among the repeated measures and subsequent estimation of the normalized eigenvalues and eigenvectors. Among the estimated eigenvectors, the one that has elements with the same sign and close magnitudes is identified, because it best expresses the genotypes' trend of maintaining their relative rankings in different periods of time. The coefficient was estimated as follows:

$$
r=\frac{\hat{\lambda}_{1}-1}{\eta-1}
$$

where $\hat{\lambda}_{1}$ is the eigenvalue of the correlation matrix associated with the eigenvector whose elements have the same sign and similar magnitude; and $\eta$ is the number of measurements.

Using the method based on the phenotypic variance-covariance matrix, the repeatability coefficient was obtained as follows:

$$
r=\widehat{\rho}=\frac{\hat{\lambda}_{1}-\hat{\sigma}_{Y}^{2}}{\hat{\sigma}_{Y}^{2}(\eta-1)}
$$

where $\hat{\lambda}_{1}$ is the eigenvalue of the phenotypic variance-covariance matrix associated with the eigenvector whose elements have the same sign and similar magnitude; $\sigma_{Y}^{2}=\sigma_{g}^{2}+\sigma^{2}$ is the phenotypic variance of trait $Y$.

The structural analysis method was based on the correlation matrix only, and was estimated by the following equation:

$$
\boldsymbol{r}=\frac{2}{\eta(\eta-1)} \sum_{j} \sum_{<j^{\prime}} \boldsymbol{r}_{j j^{\prime}}
$$

In this case, the estimator of the repeatability coefficient corresponds to the arithmetic mean of the phenotypic correlations among genotypes, considering each pair of measurements.

For each trait, the minimum number of measures necessary to obtain efficiency in the selection process, based on predefined coefficients of determination (85, 90, 95, and 99\%), was estimated by the following equation:

$$
\eta_{o}=\frac{R^{2}(1-r)}{\left(1-R^{2}\right) r}
$$

where $\eta_{0}$ is the number of measures necessary to obtain the desired coefficient of determination 
$\left(R^{2}\right)$; and $r$ is the estimated coefficient of repeatability. The repeatability coefficients and the number of collections to reach the predefined levels of determination were estimated for each plant. For each trait, the minimum number of measures necessary to obtain the predefined coefficients of determination (85, 90, 95, and 99\%) was also estimated, as described Cruz et al. (2004).

All analyses were performed using the Computer Application for Genetics and Statistics (Aplicativo Computacional em Genética el Estatística, GENES), biometrics section (Cruz, 2006).

\section{RESULTS}

For production traits corresponding to direct measurements of accumulated forage biomass and its components, the coefficients of repeatability varied between 0.265 , for STM in progeny 2 by ANOVA, and 0.769 , for LDM from progeny 3 as determined by PCCOV (Table 2).

Table 2. Coefficients of repeatability $(r)$ and determination $\left(R^{2}\right)$ of the characteristics total dry matter production, leaf dry matter, and stem dry matter in Panicum maximum hybrids, as determined by analysis of variance (ANOVA), principal components - covariance (PCCOV), principal components - correlation (PCCOR), and structural analysis (STRU).

\begin{tabular}{|c|c|c|c|c|c|c|c|c|c|}
\hline \multirow[t]{2}{*}{ Variable } & \multirow[t]{2}{*}{ Method } & \multicolumn{2}{|c|}{ Progeny 1} & \multicolumn{2}{|c|}{ Progeny 2} & \multicolumn{2}{|c|}{ Progeny 3} & \multicolumn{2}{|c|}{ Experiment } \\
\hline & & $r$ & $\mathrm{R}^{2}$ & $r$ & $\mathrm{R}^{2}$ & $\mathrm{R}$ & $\mathrm{R}^{2}$ & $r$ & $\mathrm{R}^{2}$ \\
\hline \multirow[t]{4}{*}{ Total dry matter (g/plant) } & ANOVA & 0.520 & 86.68 & 0.536 & 87.41 & 0.607 & 90.24 & 0.581 & 89.28 \\
\hline & PCCOV & 0.637 & 91.34 & 0.608 & 90.30 & 0.758 & 94.94 & 0.681 & 92.76 \\
\hline & PCCOR & 0.626 & 90.94 & 0.607 & 90.25 & 0.701 & 93.36 & 0.668 & 92.35 \\
\hline & STRU & 0.624 & 90.87 & 0.598 & 89.94 & 0.698 & 93.26 & 0.665 & 92.27 \\
\hline \multirow[t]{4}{*}{ Leaf dry matter (g/plant) } & ANOVA & 0.540 & 87.58 & 0.565 & 88.65 & 0.637 & 91.33 & 0.614 & 90.51 \\
\hline & PCCOV & 0.651 & 91.81 & 0.642 & 91.50 & 0.769 & 95.22 & 0.705 & 93.48 \\
\hline & PCCOR & 0.653 & 91.86 & 0.636 & 91.31 & 0.746 & 94.62 & 0.703 & 93.42 \\
\hline & STRU & 0.650 & 91.77 & 0.629 & 91.06 & 0.743 & 94.56 & 0.701 & 93.36 \\
\hline \multirow[t]{4}{*}{ Stem dry matter (g/plant) } & ANOVA & 0.274 & 69.38 & 0.265 & 68.44 & 0.327 & 74.50 & 0.281 & 70.19 \\
\hline & PCCOV & 0.555 & 88.22 & 0.486 & 85.02 & 0.632 & 91.17 & 0.533 & 87.26 \\
\hline & PCCOR & 0.404 & 80.24 & 0.358 & 76.98 & 0.446 & 82.88 & 0.380 & 78.59 \\
\hline & STRU & 0.396 & 79.71 & 0.348 & 76.23 & 0.419 & 81.22 & 0.371 & 77.97 \\
\hline
\end{tabular}

For TDM, the coefficients of repeatability varied from 0.520 for progeny 1 (ANOVA), to 0.758 for progeny 3 (PCCOV), both of which also provided a higher coefficient of determination (Table 2). When all plants were considered in the experiment, TDM values between 0.581 and 0.681 were found by ANOVA and PCCOV, respectively. It was observed that, regardless of the method and progeny used, the coefficients of determination were close to or above $90 \%$, indicating a good predictive ability of the genotypic value based on the repeated measures. High repeatability coefficients were also observed for the variable LDM, which varied from 0.540 for progeny 1 (ANOVA), to 0.769 , for progeny 3 (PCCOV, Table 2 ). In this regard, the repeatability values of LDM were higher than those of TDM. Considering all plants when calculating the repeatability of LDM, the values between the evaluated methods were very close. Thus, a coefficient of 0.614 was obtained by ANOVA and 0.703 by PCCOV.

In general, the repeatability values of SDM were lower compared with those from other agronomic traits, and varied from 0.265 , for progeny 2 (ANOVA), to 0.632 for progeny 3 (PCCOV) (Table 2), demonstrating a wide range between the different methods of estimation.

Out of the evaluated methods, ANOVA provided the lowest estimates of the coefficients of repeatability, whereas PCCOV provided higher estimates. The other methods, PCCOR and STRU, showed coefficient of repeatability that were intermediate to those obtained by ANOVA and PCCOV, 
although they were closer to the PCCOV method (Table 2). Marked differences between the progenies were also noted (Table 2). In this sense, the hybrids from progeny 2 provided higher repeatability than those evaluated under the same conditions. This trend was observed in different traits.

Among the morpho-agronomic traits, the repeatability coefficients varied from 0.059 for the incidence of Bipolaris maydis (IBM) in hybrids from progeny 2(ANOVA) method, to 0.773 for the same trait evaluated in the hybrids from progeny 3 (PCCOV) (Table 3). For \%L, however, repeatability oscillated between 0.118 in progeny 1 (ANOVA), and 0.455 in the hybrids from progeny 3 (PCCOV), and was thus considered to be of low-to-medium magnitude. The coefficient of determination of $\% \mathrm{~L}$ was also low, indicating that the six measurements were not sufficient to provide reliability in the selection of individuals (Table 3).

Table 3. Coefficients of repeatability $(r)$ and determination $\left(R^{2}\right)$ of the characteristics percentage of leaf, plant height, regrowth, and incidence of Bipolaris maydis in Panicum maximum hybrids as determined by analysis of variance (ANOVA), principal components - covariance (PCCOV), principal components - correlation (PCCOR), and structural analysis (STRU).

\begin{tabular}{|c|c|c|c|c|c|c|c|c|c|}
\hline \multirow[t]{2}{*}{ Variable } & \multirow[t]{2}{*}{ Method } & \multicolumn{2}{|c|}{ Progeny 1} & \multicolumn{2}{|c|}{ Progeny 2} & \multicolumn{2}{|c|}{ Progeny 3} & \multicolumn{2}{|c|}{ Experiment } \\
\hline & & $r$ & $\mathrm{R}^{2}$ & $r$ & $\mathrm{R}^{2}$ & $r$ & $\mathrm{R}^{2}$ & $\mathrm{R}$ & $\mathrm{R}^{2}$ \\
\hline \multirow[t]{4}{*}{ Percentage of leaves (\%) } & ANOVA & 0.118 & 44.50 & 0.221 & 62.98 & 0.289 & 70.93 & 0.154 & 52.13 \\
\hline & PCCOV & 0.287 & 70.68 & 0.346 & 76.02 & 0.455 & 83.36 & 0.236 & 64.93 \\
\hline & PCCOR & 0.226 & 63.68 & 0.241 & 65.59 & 0.321 & 73.94 & 0.252 & 66.86 \\
\hline & STRU & 0.173 & 55.58 & 0.213 & 61.92 & 0.274 & 69.31 & 0.191 & 58.69 \\
\hline \multirow[t]{4}{*}{ Plant height (cm) } & ANOVA & 0.607 & 86.06 & 0.534 & 82.07 & 0.534 & 82.07 & 0.651 & 88.20 \\
\hline & PCCOV & 0.654 & 88.32 & 0.558 & 83.49 & 0.571 & 84.19 & 0.684 & 89.63 \\
\hline & PCCOR & 0.638 & 87.56 & 0.570 & 84.13 & 0.600 & 85.72 & 0.684 & 89.64 \\
\hline & STRU & 0.636 & 87.46 & 0.567 & 83.97 & 0.594 & 85.39 & 0.682 & 89.55 \\
\hline \multirow[t]{4}{*}{ Regrowth } & ANOVA & 0.389 & 65.66 & 0.296 & 55.77 & 0.374 & 64.20 & 0.385 & 65.22 \\
\hline & PCCOV & 0.390 & 65.70 & 0.446 & 70.75 & 0.460 & 71.84 & 0.430 & 69.33 \\
\hline & PCCOR & 0.399 & 66.60 & 0.302 & 56.49 & 0.385 & 65.21 & 0.387 & 65.45 \\
\hline & STRU & 0.394 & 66.11 & 0.280 & 53.86 & 0.368 & 63.61 & 0.377 & 64.52 \\
\hline \multirow[t]{4}{*}{ Incidence of $B$. maydis } & ANOVA & 0.549 & 85.89 & 0.059 & 23.98 & 0.751 & 93.78 & 0.705 & 92.29 \\
\hline & PCCOV & 0.580 & 87.35 & 0.381 & 75.47 & 0.773 & 94.45 & 0.733 & 93.20 \\
\hline & PCCOR & 0.559 & 86.38 & 0.115 & 39.39 & 0.763 & 94.16 & 0.717 & 92.67 \\
\hline & STRU & 0.555 & 86.17 & 0.062 & 24.84 & 0.763 & 94.14 & 0.715 & 92.60 \\
\hline
\end{tabular}

The coefficients of repeatability for the plant-height trait were also higher, ranging from 0.534 in progenies 2 and 3 when evaluated by ANOVA, to 0.684 when considering all plants of the experiment by the PCCOV method. This trait showed more consistent repeatability coefficients, which varied less among the progenies; irrespective of the evaluated progeny, repeatability values were above 0.50 .

The coefficients of repeatability of the regrowth trait varied from 0.280 to 0.460 and these values were only higher than $\% \mathrm{~L}$ (Table 3 ). A small range of variation between the progenies was observed for this variable. As a result of the low repeatability, low coefficients of determination were also recorded, varying from 54.86 to 71.84 , indicating that the number of repeated measures taken was insufficient to provide good accuracy in their selection, and that more evaluations are necessary. The coefficients of repeatability for IBM were in general high, except for progeny 2 , and varied from 0.059 for this progeny when evaluated by ANOVA to 0.717 for progeny 3 by PCCOV. In progeny 2 , however, the coefficients varied between 0.059 and 0.381 (Table 3 ).

Progenies 1 and 3 , which resulted from a crossing between Tanzania grass and sexual parents, differed in regard to IBM due to the susceptibility of the parent. In progeny 1 , values of $\sim 0.55$ for the different methods and six measurements were sufficient to provide $85 \%$ efficiency 
at selection. For progeny 3 , however, the repeatability coefficients varied from 0.751 to 0.773 , providing a coefficient of determination of around $94 \%$ for six measurements. Considering all plants from the experiment, a similar response pattern to that of progeny 3 with high efficiency was observed for the selection of plants with coefficients of determination $\sim 92$ and $96 \%$, respectively.

Regarding the number of measures necessary to obtain predefined determination coefficients, 2-6 evaluations were necessary to achieve an efficiency of $90 \%$ when predicting the genotypic value of traits TDM and LDM. This value varied between the evaluated progenies; however, when the combined evaluation of all individuals of the experiment was considered, 3-5 collections were necessary for $90 \%$ efficiency and 6-10 were necessary for $95 \%$ (Table 4).

\begin{tabular}{|c|c|c|c|c|c|}
\hline Variable & $\mathrm{R}^{2}$ & Progeny 1 & Progeny 2 & Progeny 3 & Experiment \\
\hline \multirow[t]{4}{*}{ Total dry matter (g/plant) } & 0.85 & 3.4 & 3.7 & 2.4 & 2.8 \\
\hline & 0.90 & 5.4 & 5.8 & 3.8 & 4.5 \\
\hline & 0.95 & 11.4 & 12.3 & 8.1 & 9.4 \\
\hline & 0.99 & 59.2 & 64.2 & 42.3 & 49.2 \\
\hline \multirow[t]{4}{*}{ Leaf dry matter (g/plant) } & 0.85 & 3.0 & 3.2 & 1.9 & 2.4 \\
\hline & 0.90 & 4.8 & 5.1 & 3.1 & 3.8 \\
\hline & 0.95 & 10.1 & 10.9 & 6.5 & 8.0 \\
\hline & 0.99 & 52.7 & 56.5 & 33.8 & 41.8 \\
\hline \multirow[t]{4}{*}{ Stem dry matter (g/plant) } & 0.85 & 8.4 & 10.2 & 7.0 & 9.3 \\
\hline & 0.90 & 13.3 & 16.1 & 11.2 & 14.7 \\
\hline & 0.95 & 28.1 & 34.1 & 23.6 & 31.1 \\
\hline & 0.99 & 146.3 & 177.6 & 122.7 & 161.8 \\
\hline \multirow[t]{4}{*}{ Percentage of leaves (\%) } & 0.85 & 19.4 & 17.8 & 12.0 & 16.9 \\
\hline & 0.90 & 30.8 & 28.3 & 19.0 & 26.8 \\
\hline & 0.95 & 65.0 & 59.8 & 40.2 & 56.5 \\
\hline & 0.99 & 338.7 & 311.6 & 209.4 & 294.5 \\
\hline \multirow[t]{4}{*}{ Plant height $(\mathrm{cm})$} & 0.85 & 3.2 & 4.3 & 3.8 & 2.6 \\
\hline & 0.90 & 5.1 & 6.8 & 6.0 & 4.2 \\
\hline & 0.95 & 10.8 & 14.3 & 12.7 & 8.8 \\
\hline & 0.99 & 56.3 & 74.7 & 66.0 & 45.8 \\
\hline \multirow[t]{4}{*}{ Regrowth } & 0.85 & 8.4 & 13.1 & 9.1 & 9.0 \\
\hline & 0.90 & 13.4 & 20.8 & 14.4 & 14.3 \\
\hline & 0.95 & 28.3 & 43.9 & 30.4 & 30.1 \\
\hline & 0.99 & 147.5 & 228.7 & 158.4 & 156.8 \\
\hline \multirow[t]{4}{*}{ Incidence of Bipolaris maydis } & 0.85 & 4.5 & 43.6 & 1.8 & 2.2 \\
\hline & 0.90 & 7.1 & 69.3 & 2.8 & 3.6 \\
\hline & 0.95 & 15.0 & 146.2 & 5.9 & 7.5 \\
\hline & 0.99 & 78.0 & 761.8 & 30.7 & 39.2 \\
\hline
\end{tabular}

For variable SDM, a large number of repeated measures were necessary to obtain higher coefficients of determination - between seven and 10 were required to achieve $85 \%$, and $28-34$ collections were required to raise this coefficient to $95 \%$. Similar results were also reported for the morpho-agronomic trait percentage of leaves, wherein the six measurements taken in the study were not sufficient to achieve $85 \%$ efficiency in the selection of hybrids, which would require 12 and 20 collections, depending on the evaluated progeny (Table 4). The same trend was also observed for the regrowth trait, for which 9-13 measurements were necessary for $85 \%$, and $28-34$ measures were required to reach $95 \%$.

The predefined coefficients of determination were achieved with the number of repeated measures taken in the experiment, since 5-7 collections were necessary for $90 \%$ determination (Table 4). Even with these results, increasing the coefficient of determination to $95 \%$ implied twice the number of repeated measures. 
The incidence of $B$. maydis in $P$. maximum hybrids showed a different behavior among the progenies, wherein progenies 1 and 2 required a lower number of collections (2-5) to obtain a coefficient of determination close to $85 \%$, whereas 44 repeated measures would be necessary to obtain the same value in progeny 2.

\section{DISCUSSION}

The coefficients of repeatability of the production traits apart from stem dry weight, were higher, indicating that their selection and the definition of the genotypic value by repeated measures may provide better results. This is verified by the high observed coefficient of determination, which indicates that the efficiency of $P$. maximum selection is high and that six cuts are sufficient to provide reliability in the prediction of the response pattern of the different genotypes to total dry matter production. The total dry matter expresses the total amount of biomass that can be produced by the genotypes, and is of great importance for breeding as a direct means of improving the production rates of Brazilian pastures (Valle et al., 2009).

The higher coefficients of repeatability for LDM as compared with TDM indicate that its use may provide greater selection gains and may improve the efficiency of predicting the genotypic value of individuals. Indeed, LDM is better correlated with the performance of grazing animals than is TDM, because nutrients are concentrated in leaves and are therefore available to animals (Euclides et al., 1999). This feature is also associated with the easier ingestion of forage by animals (Euclides et al., 1999; Brâncio et al., 2003), which has indirect effects on the improvement of forage quality. Despite the high values, the results observed in the present study were lower than those obtained by Martuscello et al. (2007), who reported coefficients of repeatability LDM varying from 0.704 to 0.861 in families of half-siblings of $P$. maximum, and by Basso et al. (2009), who obtained, with six collections, repeatability coefficients between 0.73 and 0.84 for Brachiaria brizantha genotypes harvested in different locations.

The low coefficients of repeatability of SDM indicate that this trait has a lower genetic control than the other variables studied, resulting in a large influence of the environment and a lower reliability in selection, which is performed in order to reduce its participation in the forage morphological composition. Diversified climatic conditions may occur when plants are harvested during fixed regrowth periods, e.g., high temperatures and precipitation in the summer, with a subsequent reduction in the rainy-dry transition and dry season. Thus, plants that grew at higher temperatures and precipitation reached a critical leaf area index earlier and had overdeveloped stems, whereas those that sprouted under less favorable conditions still directed the partition of the photoassimilates to leaf production.

The participation of stems in the morphological composition of forage has been utilized directly in breeding; however, selection for $\% \mathrm{~L}$ allows for indirect gains in this variable. This is because $\% \mathrm{~L}$ measures the participation of the leaf-blade component in the dry green forage matter, which consists of the sum of the masses of leaves and stems, thus causing a high and negative correlation between the two variables.

Regarding the different methods used to estimate the coefficient of repeatability, the lower values predicted by ANOVA and the higher values predicted by the multivariate models were also observed in other studies evaluating P. maximum genotypes (Cargnelutti Filho et al., 2004; Martuscello et al., 2007; Lédo et al., 2008). According to Martuscello et al. (2007), the different estimates of repeatability coefficients obtained by the adopted methods indicate the need to employ multiple methods to obtain a precise interval within which the actual value of the parameter 
can be found with a greater probability. In contrast, identification of better-suited methods to evaluate forage traits can also be adopted as a strategy to improve the estimate of this parameter. The repeatability coefficients also varied among the evaluated progenies, which is probably due to greater segregation among the individuals, higher genotypic variance, and greater stability of the response throughout the repeated measures, thus resulting in a higher degree of correlation among these measures.

The low repeatability observed for $\% \mathrm{~L}$ diverges from the results published by Martuscello et al. (2007), who obtained higher individual repeatability, which varied between 0.639 and 0.707 in families of half-siblings of $P$. maximum. Conversely, Lédo et al. (2008), observed coefficients closer to those found in the current study when evaluating $23 P$. maximum genotypes in 15 harvests. According to these authors, the repeatability of \%L varied between 0.167 and 0.392 using the same methods for repeatability estimation as those adopted in our study. Hence, the conditions under which the study was carried out may have provided a higher response to the environment. Another possible explanation is the oscillation in the climatic conditions over the repeated measures, which increase residual variance. Therefore, to improve the results of selection and prediction of the genotypic value of $\% \mathrm{~L}$, it is necessary to increase the number of measures or to utilize measures that can be performed in both rainy and dry seasons as two distinct variables. This approach has been adopted in some studies on forage breeding (Ferreira et al., 1999; Botrel et al., 2000; Martuscello et al., 2009; Ferreira et al., 2010).

The low repeatability coefficients indicate that \% also has low heritability, since repeatability expresses the maximum value that heritability can take (Falconer and Mackay, 1996). Nevertheless, $\% \mathrm{~L}$ is essential in forage breeding, and being a low-repeatability trait in full-sibling hybrids of $P$. maximum, it can be improved genetically through strategies such as correlated response. In fact, \%L is correlated with LDM, which provides greater accuracy in the prediction of performance in this and in other studies (Cargnelutti Filho et al., 2004; Martuscello et al., 2007; Lédo et al., 2008).

Plant height $(\mathrm{PHT})$ is directly linked to the management required by tropical forages. In this study, results indicate that selection for this trait can be very successful given the high coefficients of determination obtained. Similar values were also observed by Lédo et al. (2008), who found coefficients of repeatability between 0.603 and 0.748 for plant height in accessions of $P$. maximum.

Regrowth is one of the traits assessed during the initial stages of the breeding process, because it is easy and rapid to measure (Jank et al., 2008); this variable has been evaluated by assigning scores that are capable of representing those plants that have a greater ability to recover after defoliation. However, in the present study, hybrids showed low repeatability throughout the different harvests. The repeatability of the regrowth trait was also evaluated by Figueiredo et al. (2012) in accessions of Brachiaria humidicola, who observed coefficients of repeatability and determination of 0.809 and $97.45 \%$, respectively, between nine measurements.

The incidence of $B$. maydis (IBM) has received greater attention in the genetic breeding of $P$. maximum, because the occurrence of this Helminthosporium has been recently reported in Tanzania grass. According to Martinez et al. (2010), this fungus can impair forage production and plant tillering, which are essential to the sustainability of a pasture. In this sense, selection for more resistant plants or plants that hold a larger number of traits favorable for lower incidence is paramount for the diversification of pastures with $P$. maximum.

The analysis of the IBM results indicated that there were substantial differences between progenies, which may be associated with the degree of susceptibility of the parents. Thus, by ANOVA, progeny 2 had values close to zero due to the little variation for IBM within this progeny, which showed pathogen resistance, with low or no incidence among its hybrids. The genotypic 
variance for this trait was probably low, which contributed to the reduced repeatability coefficient and also to the low covariance among the repeated measures. This result indicates that the mombaça grass can serve as a source of pathogen resistance in breeding programs of this species.

There was a broad range of variation between the estimated repeatability values for IBM among the evaluated methods within progeny 2 (Table 3); the lowest values were estimated by ANOVA (0.059), and the highest by the PCCOV method (0.381). These results can be explained by the fact that the principal component analysis method shows a substantial bias when the actual value of the repeatability coefficient is low, as demonstrated by Mansour et al. (1981). Therefore, when the actual value of the coefficient approaches zero, methods based on the principal component analysis overestimate the repeatability. It was also observed that, irrespective of the evaluated trait, ANOVA resulted in the lowest values among all methods. According to Cruz et al. (2004), this method may in some cases overestimate repeatability.

Analysis of the coefficient of repeatability also allows us to estimate the number of measures necessary to obtain the predefined coefficients of determination (Table 4). Thus, increased efficiency in the selection process implied a considerable increase in the number of measurements, and this means that attempts to increase precision to over 95\% would require a significant increase in the number of measures in relation to the gain in precision, and is therefore not justified.

The number of repeated measures necessary to increase the coefficient of determination from 90 to $95 \%$ in TDM and LDM may be considered moderate, and its application in routine breeding programs will depend on its objectives and on the available financial resources for its implementation. In a similar study, Daher et al. (2004) needed 17 collections to achieve $90 \%$ efficiency when selecting elephant grass (Pennisetum purpureum) genotypes using the principal component analysis method based on the correlation matrix.

The low repeatability coefficient detected for SDM resulted in a large number of collections or evaluations to achieve the predefined coefficients of determination (Table 4). These results are probably due to the effect of the development of the forage canopy on the accumulation of stems, given that this trait is largely influenced by environmental conditions, especially competition for light (Carnevalli et al., 2006). The same explanation can be used for the large number of repeated measures necessary to obtain higher coefficients of determination for \%L. This trait is influenced at the moment of collection in forage plants, which signifies low genetic and high environmental control.

The regrowth rate also contributed to the reduced coefficient of determination of the morpho-agronomic traits, requiring a large number of repeated measures to improve the efficiency in predicting the actual genotypic value of $P$. maximum hybrids. This trait also received great importance in the initial stages of the breeding program due to its ease of measurement (Valle et al., 2009; Jank et al., 2011).

Plant height was distinct from the other morpho-agronomic traits in that it took a lower number of repeated measures to obtain the predefined determination coefficients. These results indicate the possibility of greater gains with selection of this trait and greater accuracy in predicting the genetic value based on repeated measures. The large difference observed in the number of repeated measures necessary to obtain greater efficiency in the selection of the genetic value of the hybrids for IBM may be related to the low variability of progeny 2 and also to the fact that progenies 1 and 3 resulted from a cros with Tanzania grass, which is known to be susceptible to the pathogen. Thus, crossing with resistant progenies generates hybrids with a varied degree of susceptibility, which ccan be selected with greater reliability for taking few repeated measures.

In conclusion, the repeatability of agronomic traits in P. maximum/ hybrids had coefficients that varied from low to moderate, and six collections were sufficient to provide greater reliability 
in the prediction of the response of hybrids regarding the traits total dry matter production, leaf dry matter production, incidence of $B$. maydis, and plant height. The repeatability of the traits percentage of leaves and regrowth, however, was low, and required a larger number of repeated measures to improve efficiency in the selection of individuals based on these traits.

\section{Conflicts of interest}

The authors declare no conflict of interest.

\section{ACKNOWLEDGMENTS}

The authors would like to thank Embrapa Beef Cattle, Fapemig, CNPq, and CAPES for financial support.

\section{REFERENCES}

Abeywardena V (1972). An application of principal component analysis in genetics. J. Genet. 61: 27-51.

Basso KC, Resende RMS, Valle CB, Gonçalves MC, et al. (2009). Avaliação de acessos de Brachiaria brizantha Stapf. e estimativas de parâmetros genéticos para caracteres agronômicos. Acta Sci. Agron. 31: 17-22.

Botrel MA, Ferreira RP, Cruz CD, Pereira AV, et al. (2000). Estimativas de coeficiente de repetibilidade para produção de matéria seca em cultivares de alfafa, sob diferentes ambientes. Rev. Ceres 47: 651-663.

Brâncio PA, Nascimento Jr D, Euclides VPB, Fonseca DM, et al. (2003). Avaliação de três cultivares de Panicum maximum Jacq. sob pastejo: composição da dieta, consumo de matéria seca e ganho de peso animal. R. Bras. Zootec. 32: 1037-1044.

Cargnelutti Filho A, Castilhos ZMS, Storck L and Savian JF (2004). Análise de repetibilidade de caracteres forrageiros de genótipos de Panicum maximum, avaliados com e sem restrição solar. Ciênc. Rural 34: 723-729.

Carnevalli RA, Da Silva SC, Bueno AAO, Uebele MC, et al. (2006). Herbage production and grazing losses in Panicum maximum cv. Mombaça under four grazing managements. Trop. Grasslands 40: 165-176.

Cruz CD (2006). Programa Genes, Biometria. Editora UFV, Viçosa.

Cruz CD, Regazzi AJ and Carneiro PCS (2004). Modelos biométricos aplicados ao melhoramento genético. Editora UFV, Viçosa.

Daher RF, Maldonado H, Pereira AV, Amaral Junior AT, et al. (2004). Estimativas de parâmetros genéticos e de coeficientes de repetibilidade de caracteres forrageiros em clones de capim-elefante (Pennisetum purpureum Schum.). Acta Sci. Agron. 26: 483-490.

Di Renzo MA, Ibañez MA, Bonamico NC and Poverene MM (2000). Estimation of repeatability and phenotypic correlations in Eragrostis curvula. J. Agric. Sci. 134: 207-212.

Euclides VPB, Thiago LRLS, Macedo MCM, Oliveira, MP (1999). Consumo voluntário de forragem de três cultivares de Panicum maximum sob pastejo. R. Bras. Zootec. 28: 1177-1185.

Falconer DS and Mackay TFC (1996). Introduction to quantitative genetics. Longman, Essex.

Ferreira RP, Botrel MA, Pereira AV and Cruz CD (1999). Avaliação de cultivares de alfafa e estimativas de repetibilidade de caracteres forrageiros. Pesq. Agropec. Bras. 34: 995-1002.

Ferreira RP, Vasconcellos ES, Cruz CD, Barioni JR W, et al. (2010). Determinação do coeficiente de repetibilidade e estabilização genotípica das características agronômicas avaliadas em genótipos de alfafa no ano de estabelecimento. Rev. Ceres 57: 642-647.

Figueiredo UJ, Nunes JAR andValle CB (2012). Estimation of genetic parameters and selection of Brachiaria humidicola progenies using a selection index. Crop Breed. Appl. Biotechnol. 12: 237-244.

Jank L, Resende RMS and Valle CB (2008) Melhoramento genético de Panicum maximum. In: Melhoramento de Forrageiras Tropicais (Resende RMS, Valle CB and Jank L eds.). Embrapa, Campo Grande, 55-87.

Jank L, Valle CB and Resende RMS (2011). Breeding tropical forages. Crop Breed. Appl. Biotechnol. Special edition: 27-34.

Lédo FJS, Pereira AV, Sobrinho FS, Auad AM, et al. (2008). Estimativas de repetibilidade para caracteres forrageiros em Panicum maximum. Ciênc. agrotec. 32: 1299-1303.

Mansour H, Nordheim EV and Rutledge JJ (1981). Estimators of repeatability. Theor. App/ Genet. 60: 151-156.

Martinez AS, Franzener G and Stangarlin JR (2010). Dano causado por Bipolaris maydis em Panicum maximum cv. Tanzânia. Semin. Cienc. Agrar. 31: 863-870. 
Martuscello JA, Jank L, Fonseca DM, Cruz CD, et al. (2007). Repetibilidade de caracteres agronômicos em Panicum maximum Jacq. R. Bras. Zootec. 36: 1975-1981.

Martuscello JA, Jank L, Fonseca DM, Cruz CD, et al. (2009). Among and within family selection and combined half-sib family selection in Panicum maximum Jacq. R. Bras. Zootec. 38: 1870-1877.

Shimoya A, Pereira AV, Ferreira RP, Cruz CD, et al. (2002). Repetibilidade de características forrageiras do capim-elefante. Sci. Agric. 59: 227-234.

SIDRA-IBGE. Instituto Brasileiro de Geografia e Estatística. Available at: http://www.sidra.ibge.gov.br/bda/tabela/listabl. asp?z=t\&o=1\&i=P\&e=I\&c=264. Accessed April 15, 2011.

Valle CB, Jank L and Resende RMS (2009). O melhoramento de forrageiras tropicais no Brasil. Rev. Ceres 56: 460-472. 